\title{
Archaeobotanical results from Sarazm, Tajikistan, an Early Bronze Age Settlement on the edge: Agriculture and exchange
}

\author{
Robert N. Spengler III ${ }^{1}$, George Willcox ${ }^{2}$
}

${ }^{1}$ Anthropology Department, Washington University in St. Louis, St. Louis, MO 63130, USA, ${ }^{2}$ Archéorient CNRS UMR 5133, Université de Lyon II, Antenne d’Archéorient, Jalès, Berrias, 07460 St-Paul-le-Jeune, France

Sarazm is an agricultural settlement located in the Zerafshan Valley of northwestern Tajikistan; it was occupied from the fourth to the end of the third millennia BC. Located on the northeastern edge of a chain of agricultural settlements (Namazga IV) that span the northern foothill ecotone of the Kopet Dag, Sarazm sat on a crossroads of exchange and interaction. Being at the eastern extremity of this chain of sedentary villages, Sarazm is the key site for understanding the eventual diffusion of agriculture north into the mountains and steppe. The main purpose of this article is to present a long-awaited (previously unpublished) macrobotanical data set analysed in the late 1980s by George Willcox. Domesticated seeds in the assemblage (wheat and barley) are important both in terms of understanding the northeastern spread of agriculture into Central Eurasia and illustrating the role of agriculture in the Early Bronze Age economy at Sarazm. Wild fruit remains (specifically Russian olive, hackberry, sea buckthorn berry, wild pistachio and cappers) attest to foraging practices.

Keywords: Sarazm, Tajikistan, Agriculture, Exchange, Bronze Age

\section{Introduction}

Sarazm is an Eneolithic (Chalcolithic)/Early Bronze Age agricultural urban outpost, occupied from the fourth until the end of the third millennia $\mathrm{BC}$ (ca 3500-2000 BC, all the dates mentioned are uncalibrated) (Besenval 1987, 2001; Besenval and Isakov 1989; Lyonnet and Isakov 1996; Razzokov 2008; Fig. 1). The name 'Sarazm' translates to 'the edge (or beginning) of the land', an appropriate name due to the site's location at the end of the chain of Namazga Culture sedentary village sites that spanned the Kopet Dag foothills as far east as the Pamir Mountains. It is also just south of the southernmost (or beginning) of the northern Central Asian sites. Early Bronze Age populations in northern Central Asia are poorly studied and little is known of their economy (Frachetti and Mar'yashev 2007). In the Middle Bronze Age, there are material culture similarities among steppe and mountain groups, hence archaeologists often clump them into a broad, poorly defined agglomerate called the 'Andronovo Cultural Complex'. The economy of these populations is often argued to be primarily pastoral, with transhumance (for discussion, see Frachetti 2008). Therefore,

Correspondence to: Robert Spengler III, Anthropology Department, Washington University in St. Louis, CB 1114, One Brookings Dr., St. Louis, MO 63130, USA. Email: rnspengl@wustl.edu
Sarazm was truly a settlement on the edge, to the north of which was the 'steppe' world. Exchange (not necessarily manifested as stable or organised routes) flowed to the north as well as the southeast and southwest of the site.

In recent years the idea of a mountain border between East Asia and Southwest Asia has been remolded into an 'Inner Asian Mountain Corridor' (Frachetti 2012). This new model is prompting discourse relating to exchange and culture flow through Central Asia. Much of this research has focused on the movement of horse breeding and metallurgical technology into China (see Frachetti 2008). In fact, Frachetti $(2012,18-20)$ sees herding and metallurgy as key innovations that linked a panregional (across Central Asia) network of relationships among political institutions in the second millennium BC.

As a frontier settlement, Sarazm was at a key locus or node along a reticulated network of exchange and trade that facilitated (or promoted) the spread of agricultural technology and innovation as well as a variety of material culture items. Evidence for exchange at Sarazm comes from exotic goods including carved stone wares, worked coppers and beads made from carnelian, lapis lazuli, gold, turquoise, chalk, jasper, silver and a variety of colorful stones and minerals (Razzokov 2008, figure 33). There is a growing body 


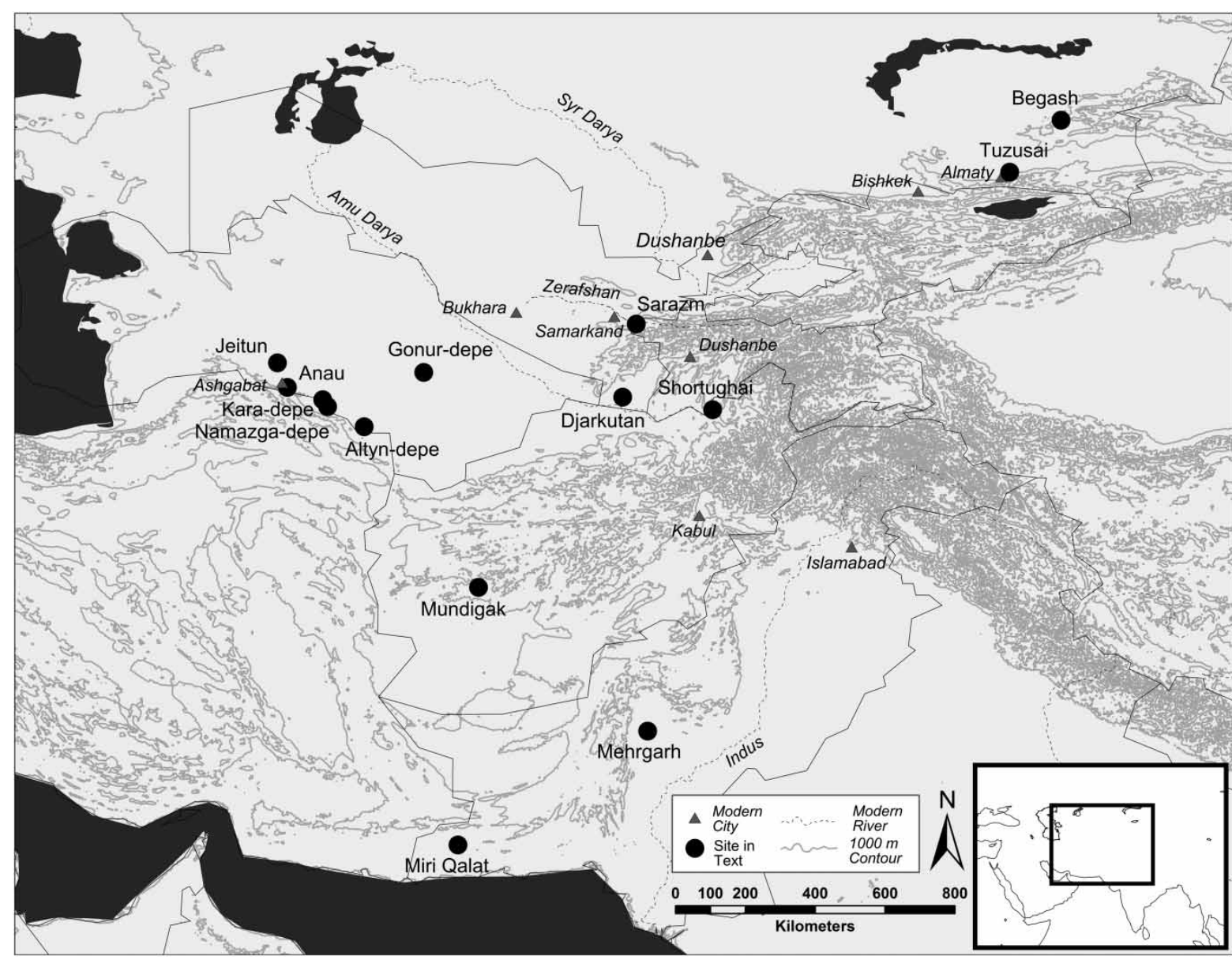

Figure 1 The position of Sarazm in relation to regional physical features and archaeological sites mentioned in the text.

of evidence attesting to this third and second millennia $\mathrm{BC}$ exchange network, such as finds of worked minerals and stones that evidently moved between the Indus Valley and Central Asia (Frachetti 2012; Kenoyer 2011; Law 2006; Possehl 2004). Archaeologists have discussed the long-distance diffusion of metals from Central Asia, south and east into Xinjiang (Kenoyer 2011; Mei 2009; Mei and Shell 1999; Thornton and Schurr 2004). Salvatori (2008, 116) envisions an

\section{intensive and complex 'international' system of long-distance exchanges between the Iranian world (Hissar, Khinaman, Shahdad, Tepe Yahya and Susa), Central Asia (piedmont of southern Turkmenistan, Bactria and Margiana), and the Indus Valley}

during the third millennium $\mathrm{BC}$. He uses numerous lines of evidence to support this conclusion, most notably cylinder stamp seals. A direct contact form of exchange has been promoted by several researchers, who argue that trading settlements (nodes in the network) linked these three regions since the middle third millennium BC (Crawford 1992; Parpola et al. 1977; Salvatori 2008; Winkelmann 2000).
Mobile pastoral populations in the Central Asian mountains, an area rich in ore resources, are usually credited with supplying metal and metalworking technology to people further east (Kenoyer 2011; Mei 2009; Mei and Shell 1999; Thornton and Schurr 2004). However, sedentary agropastoral settlements, such as Sarazm, were centres of metalworking and diffusion of metallic goods. Furthermore, a variety of other commodities, such as carnelian and lapis lazuli, spread through this corridor in the third and second millennia BC (Frachetti 2012; Kenoyer 2011; Law 2006; Salvatori 2008). An even stronger supporting data set for the Central Asian corridor is emerging out of the archaeobotanical evidence for the early spread of agriculture east and west through this corridor (Frachetti et al. 2010). Fuller (2009) refers to this as the 'Middle Asian Corridor of Crop Exchange and Agricultural Innovation'. This corridor of exchange may have indirectly brought agricultural products and technology, including domestic seeds, from southern Central Asia and the Indus Valley into China, and vice versa.

Sarazm sits at a three-way point of intersection along the corridor, bringing in material and intellectual culture from agricultural villages along the northern Kopet Dag foothills, the agricultural settlements 
along the eastern Iranian Plateau and possibly as far east as the Indus Valley, and mobile pastoral populations in the mountains of the Tien Shan (poorly understood before $2500 \mathrm{BC}$ ). As Isakov et al. (1987, 102) state,

the materials from Sarazm have direct parallels with materials from the west (Turkmenistan), the south (Baluchistan and Iran) and the north (the Steppes of Kazakhstan).

\section{The Sarazm site}

Location and size

The site is located on the Samarkand plain, situated on an alluvial terrace at the mouth of the Zerafshan river valley in northwestern Tajikistan (Razzokov 2008; Fig. 1). The valley cuts through the Western Pamir Mountains (more specifically the Fann Mountains). The mountains peak about $50 \mathrm{~km}$ from the site, reaching 5500 masl; however, further east the range rises to 7495 masl at its highest (Peak Ismoil Somoni). The site is located in the foothill zone at 900 masl (Besenval and Isakov 1989; Fig. 2). The mountains are snowcapped year round, and mountain rain and glacial melt feed numerous streams. The site is $15 \mathrm{~km}$ west of the modern town of Penjikent and $60 \mathrm{~km}$ east of Samarkand. Two small villages, Avazali and Sokhibnazar, sit on opposite ends of the site and obstruct much of the site's surface area; the visible area of Sarazm is 35 ha. However, Isakov $(1980,273)$ suggests that the site could be up to 90 ha in area and Besenval and Isakov (1989) as much as 100-150 ha. The stratigraphic depth of the site varies, but never exceeds 2 meters (Besenval and Isakov 1989). Besenval and Isakov (1989) interpret this shallow depth of sediment, deposited over a millennium of occupation, as evidence for phases of abandonment and structural erosion.

\section{Excavation and chronology}

Excavations at Sarazm spanned (in phases) from 1977 until the present, through varying waves of international collaboration (for discussion, see Besenval 2001; Razzokov 2008). This article presents the results of a macrobotanical study, including wood analysis, conducted in 1990 by George Willcox. The study was conducted as part of a series of joint French and Soviet excavations (Besenval 2001; Lyonnet and Isakov 1996). Due, in part, to the dissolution of the Soviet Union 1 year after the completion of the study, the report was never published in full. However, a summary of the preliminary results was presented in Razzokov (2008). In light of the importance of Sarazm in recent discussions regarding exchange and agricultural spread (see Frachetti 2012), Willcox decided to present this long-awaited data set here. Excavations in Central Asia over the past two decades have served to further illustrate the importance of Sarazm, allowing us to contextualise the site into a broader archaeological landscape of exchange and material and intellectual culture flow.

Even if we accept that Isakov's (1980) estimate of 90 ha is inflated, the visible 35-ha area still makes Sarazm a larger settlement or proto-urban center than any of its known contemporaries in southern Central Asia, even those of the second millennium BC. Gonur Depe (Fig. 1), at 22 ha is the largest center in Margiana (Sarianidi 1993), and Shortughai (Fig. 1) consists of two mounds, each only 2 ha in extent. The chronology for Sarazm was refined during the Soviet/American excavations in 1985 (Isakov et al. 1987) and further confirmed by Besenval's excavations in 1988-1990. Sarazm was divided into three occupation phases: (I) the early fourth millennium BC; (II) the later fourth and early third; (III) some occupation at the site may have lasted into the latter half of the third millennium BC. This chronology was slightly revised by Razzokov $(2008,25)$ to $3500-2900$ BC (Sarazm I), 2900-2600 BC (Sarazm II), 2600-2300 BC (Sarazm III) and 2300-2000 BC (Sarazm IV). For the purpose of this article, we are dealing with six distinct excavation events, numbered II-VII. Excavations I-VI were conducted from 1977-1985 under the directorship of A. Isakov (Isakov 1980; Lyonnet and Isakov 1996). The majority of the archaeobotanical samples discussed here were excavated during the period from 1988-1990 by R. Besenval and his team (excavation area VII, an area of $16 \times 20 \mathrm{~m}$ ) (for a discussion of these excavations, see Besenval 1987, 2001; Besenval and Isakov 1989; Isakov 1980; Lyonnet and Isakov 1996; Razzokov 2008). Excavation areas (units) are matched with flotation samples (FSs) in Table 1.

\section{Material culture and economy}

Architecture consists of multi-room complexes composed of rectangular rooms with corridors (Razzokov 2008; Fig. 3). Isakov (1980, 278) suggests that corridor-shaped rooms without entry ways may have been used for storage. Architecture consisted of a mix of adobe and mud brick styles. While architecture at Sarazm is similar to Namazga sites, the closest line of evidence connecting the Zerafshan Valley to sites in the Kopet Dag piedmont, which is situated some $500 \mathrm{~km}$ to the southwest, is the polychrome pottery. Kircho (1980, 102-105) discusses the compositional patterns and ornamentation styles which characterise Namazga pottery. Isakov distinguishes two painted ceramic traditions at Sarazm:

Polychrome ceramics form the first group; darkbrown and dark-rose designs are places on red 


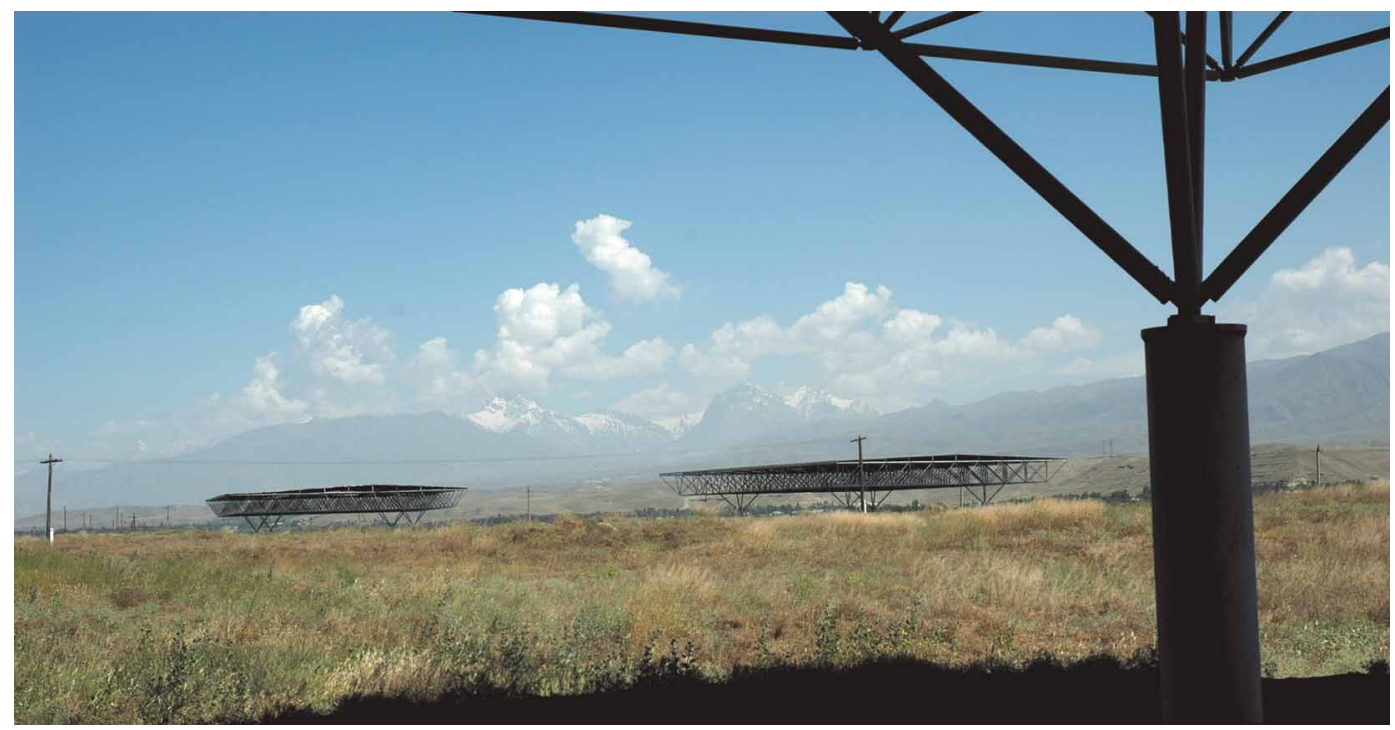

Figure 2 Photo of Sarazm with UNESCO constructed roofs protecting open excavation units, and illustrating the mountain and steppe environments.

and light-yellow slipped wares... The second group consists of monochrome wares with dark-brown designs on a light background. All the painted ceramic fragments from Sarazm share broad analogies with wares from southern Turkmenia, particularly those of the Namazga IV period. Separate fragments with triangles and sawed designs inside rectangles are similar to ceramics from the upper levels of Geoksyur and Kara-depe (Isakov 1980, 278).

In addition to the observations of Besenval (1987), Isakov (1980), Lyonnet and Isakov (1996) and Razzokov (2008) that ceramics at Sarazm are Namazga-like, other material culture similarities exist, including lapis lazuli beads, spindle whorls, grinding stones, mortars, jambs and whetstones. Sarazm has material culture similarities to contemporaneous Namazga IV and V sites along the Kopet Dag piedmont such as Altyn Depe, Kara Depe and Namazga Depe (Fig. 1) (Masson 1980). Kohl (1980, 22) refers to Sarazm and Zamanbaba (a site near the Bukhara Oasis) as 'Namazga-related communities'. He notes that they have a mixture of 'steppe' and southern Bactrian material culture remains, possibly suggesting a north/south exchange.

Early in the excavations at Sarazm it was noted that there were uncharacteristically (for southern Central Asia) abundant finds of metal objects (Isakov 1980). In addition, there were significant finds of slag and crucibles, specifically from excavation II in 1985, dating to Sarazm III. A detailed study of the Sarazm metals was conducted by Isakov et al. (1987); they concluded that copper was processed in a similar fashion to contemporary coppersmiths in Mesopotamia, the Iranian Plateau and the Indus Valley. Significant changes in metal processing took place during the second half of the third millennium $\mathrm{BC}$ in the Namazga IV Culture (discussed in Terekhova 1980, 323-326). Sarazm is often regarded as being a metallurgical and mineral/stone carving site involved in processing ore and minerals from the Zerafshan Valley. Lyonnet and Isakov (1996) also discuss the site of Tugaï, Uzbekistan, a specialised metallurgical site several kilometers downstream of Sarazm along the Zerafshan. Tugaï not only shows evidence for a specialisation in metal processing but also has material culture similarities to what Lyonnet and Isakov (1996, 117-124) call 'Andronovo'. Tugaï was excavated in 1992. Other evidence for economic pursuits at Sarazm include copious finds of grindstones and pestles (Razzokov 2008). The faunal assemblage at the site is dominated by sheep and goat with some domestic cattle and dog. Hunting was also a component in the economy, specifically attested to by bones of gazelle (Gazelle subguturosa Güldenstaedt), wild pig, fox and birds (Razzokov 2008, 72).

\section{Environmental setting}

The Western Pamir Mountains have a varying array of environmental pockets, which are orographically determined. The Zerafshan river valley in northwestern Tajikistan is a vegetatively rich and diverse swath of land framed by rocky mountains. The vegetation of the valley today is the result of thousands of years of human impact, particularly grazing; however, the abundance of wood charcoal at the site suggests that parts of the valley were forested near the site in the past. Today, the vegetation in the valley and foothill zone is dominated by steppe plants, and is maintained through grazing by sheep, goat and to some extent cattle (see Fig. 2). 
Table 1 Archaeobotanical results from the 1990 analysis at Sarazm (excluding charcoal)

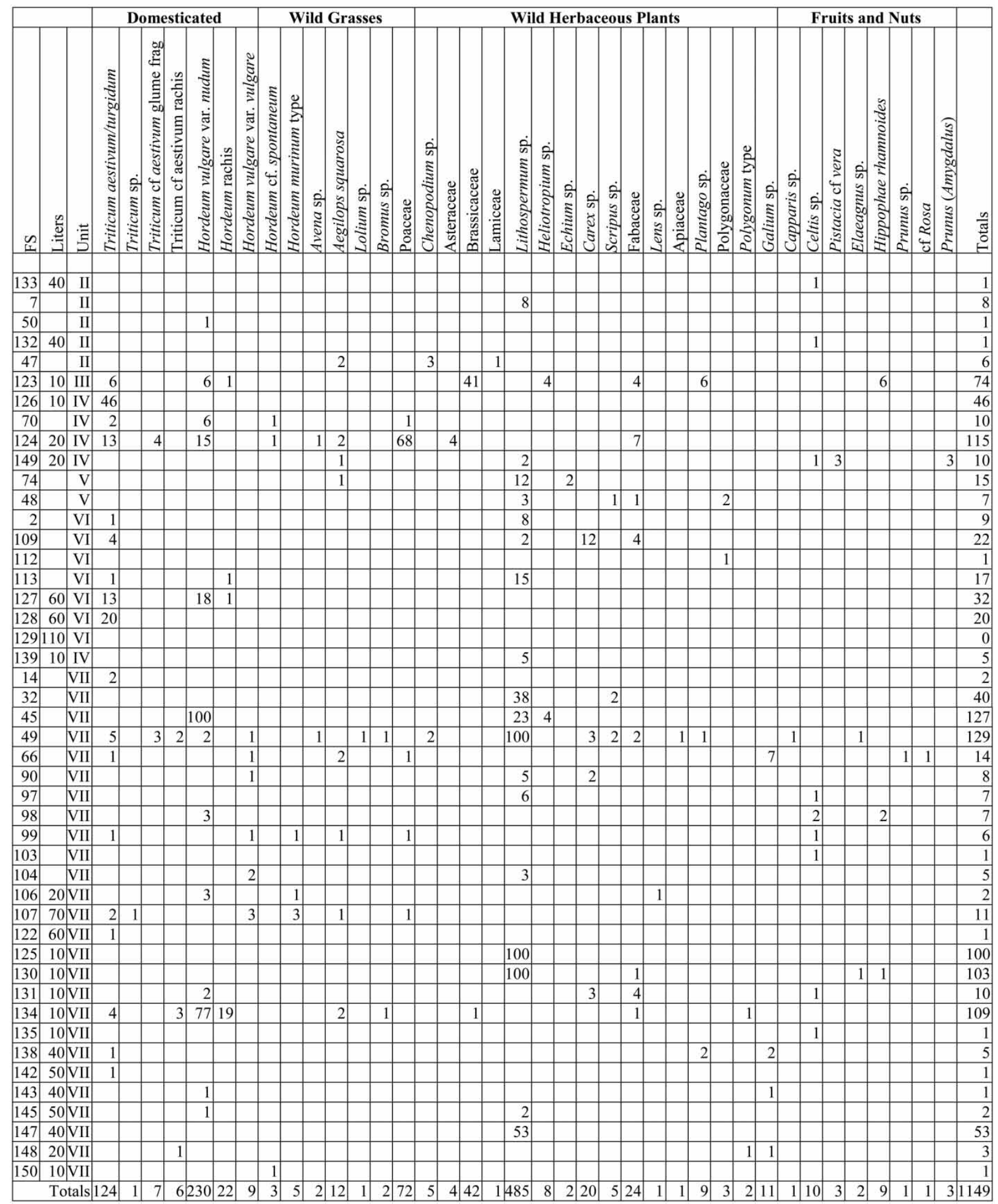

As with most Central Asian archaeological sites, Sarazm is located in a foothill ecotone. Being situated on an elevated alluvial terrace allows for easy access to natural resources in the valley (riparian forests and arable land) and in the mountains (mountain meadows and fruit and nut trees). Annual rainfall in the valley it is often greater than $250 \mathrm{~mm}$ (as much as $300-400 \mathrm{~mm}$ according to Besenval and Isakov 1989), allowing dry-farming, although irrigation is also practiced. The use of most of the valley for modern farming has further altered the ecological dynamics of the valley.

During Willcox's (1991) vegetation surveys, isolated forest patches were found at an elevation of 1500 masl, north of the Zerafshan. These forest patches were dominated by maple (Acer spp.), wild almond (Prunus sp. subgenus Amygdalus), Celtis sp. and wild pistachio (Pistacia vera L.). It is reasonable to 


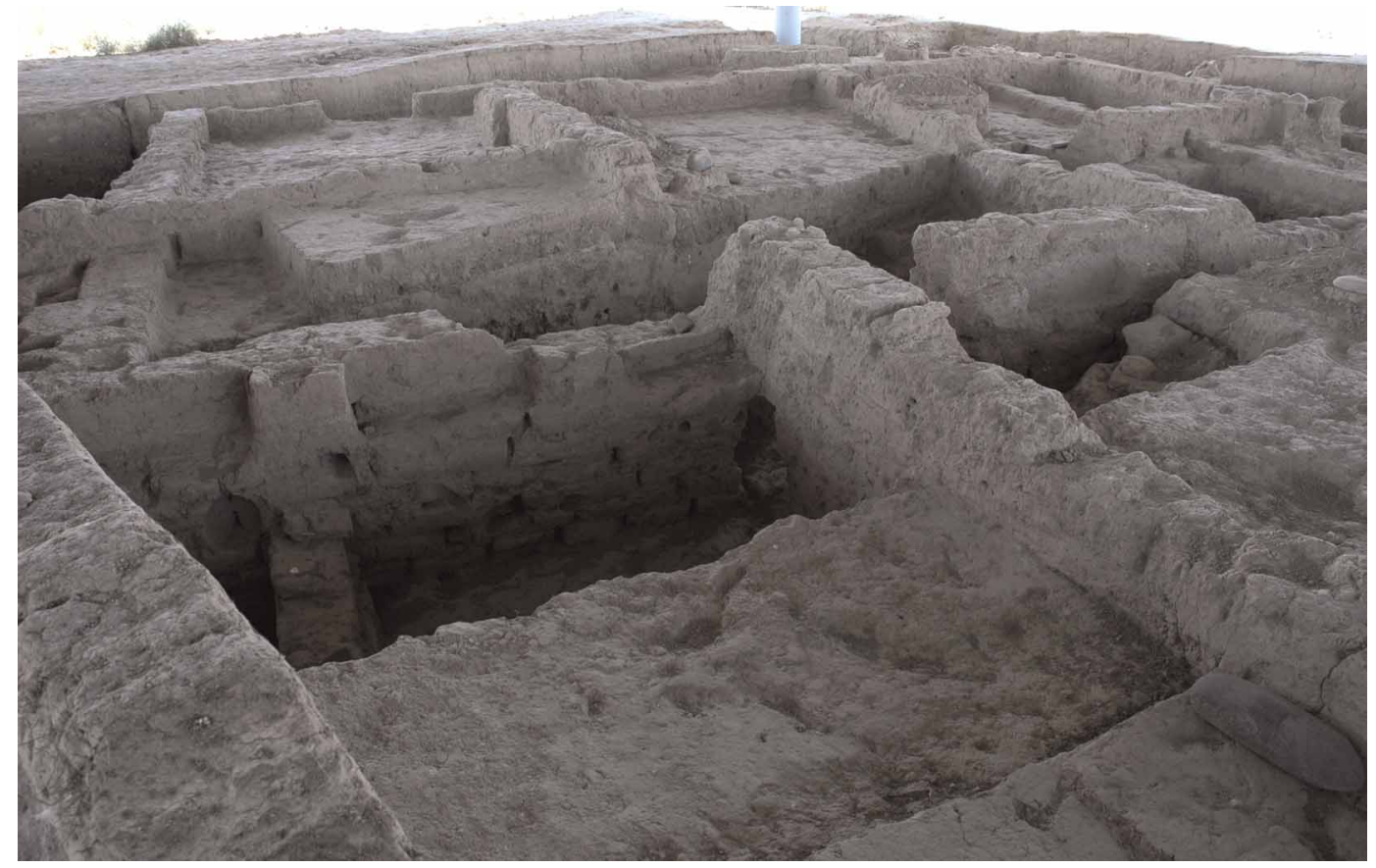

Figure 3 Photo of preserved excavation unit at Sarazm with mud-brick architecture visible.

hypothesise, in light of the wood analysis at Sarazm, that these species grew at lower elevations closer to the site during the Early Bronze Age. Riparian forests are currently still in existence and are dominated by Russian olive (Elaeagnus angustifolia L.), ash (Fraxinus sp.), sea buckthorn (Hippophae rhamnoides L.), poplar (Populus sp.) and tamarisk (Tamarix sp.). The rapid regeneration of these wood resources would have made them more suitable for fuel and timber than mountain forest species (although wood fuel is often chosen for specific characters and different woods are sometimes used for different fuel-related purposes).

Shrubby mountain forests are located around an elevation of 2200 masl. At this elevation rainfall is greater and temperatures are generally lower. The woody vegetation includes barberry (Berberis vulgaris L.), cotoneaster (Cotoneaster sp.), walnut (Juglans regia L.), juniper (Juniperus sp.), wild apricots (Prunus armeniaca L.), gooseberries (Ribes sp.), mountain ash (Sorbus sp.) and elm (Ulmus sp.).

\section{Archaeobotany \\ Methods}

Flotation was conducted using an overflow-style machine designed after the one constructed by Williams (1973) for work at Siraf, Iran and similar to an Ankara Machine. For a discussion of such machines and their operation see Fritz (2005, 780-784), Pearsall (2000, 29-33) and Watson (1976, 79-80). Samples were broken down using continual water flow agitation causing separation of soil particles. Buoyant particles (charred plant remains) were caught in a mesh at the overflow spout; mesh sizes of $0.5 \mathrm{~mm}$ (for flotation) and $2.5 \mathrm{~mm}$ (wet sieve) were used.

Samples were taken from contexts that appeared to be rich in carbonised organic material, such as hearths, house floors and middens. Large samples were taken ranging from 10 to 1101 . A total of 150 samples were floated totaling about 25001 of sediment. Forty-six of these samples had sufficient material to merit analysis (presented here). Some of the flotation was conducted by Roland Besenval and his team; however, in 1990 George Willcox personally carried out the flotation. Samples were sorted in the archaeobotanical laboratory at the annex of Archéorient (CNRS) in the Ardèche.

In addition, during the field excavation of 1990 , Willcox conducted botanical surveys of the region and collected reference material to aid in identification of archaeobotanical material. This survey allows us to compare material found in the Sarazm assemblage with the modern vegetation communities at various elevations in the Zerafshan Valley.

\section{Results}

\section{Domesticated seeds}

Free-threshing hexaploid wheat rachises $(n=6)$ were recovered from three samples, suggesting that grains were grown and processed on or near the site. In addition, barley rachises $(n=22)$ came from four samples, notably FS134 (Table 1). Barley rachises were not differentiated between hulled and naked or two and six row forms in this study. The low ubiquity of rachises ( $7 \%$ for wheat and $9 \%$ for barley), may 
suggest that harvests were processed in a single event and stored in a fully cleaned form. Fuller and Stevens (2009) note that single occurrence annual events are less likely to show up in the archaeobotanical record. If grains were processed and cleaned in the autumn then rachises would be less ubiquitous even if harvesting and processing took several days. If the harvests were stored prior to threshing and processed in small amounts throughout the year, rachises would be continually introduced into the archaeological record. Because naked wheat grains tend to detach from the ear, in most areas of Eurasia they are threshed immediately after the harvest as opposed to hulled cereals which are often threshed on a daily basis.

All the wheat rachises have the characteristic morphology of hexaploid free-threshing wheat (Triticum aestivum L.); therefore, it is likely that the caryopses were from the same form of wheat. In addition, the general archaeobotanical evidence for Asia seems to suggest that glume wheats did not spread north or east any further than they already had by the fourth millennium BC, although, the data for early glume wheats in Central Asia are still limited. Glume wheats are present at Jeitun (Harris 2010) and Mehragrh (Costantini 1984, 31) (Fig. 1), but do not appear to spread beyond those points. Unlike much of the second and first millennia BC free-threshing wheat found in Central and East Asia (including the Indus Valley), the wheat grains found at Sarazm are from a lax-eared form. Both naked (Hordeum vulgare var. nudum Spenn.) and hulled (H. vulgare var. vulgare L.) forms of barley were present in the Sarazm assemblage, with naked barley being more common than hulled. Barley grains at Sarazm are short and semispherical. FS45 seems to be a small carbonised cache of naked barley. The sample comes from the fill of two small pits, T.31 and T.32 (UF 17-18/87) inside a house.

\section{Wild fruit seeds}

In addition to the domestic grains, seeds and stones from several wild edible fruit plants were recovered in the assemblage. These fruits were likely part of the diet. Ethnohistorically (before Soviet and Russian Imperial influence), foraging of wild plants was an important part of Central Eurasian mountain economies (Vainshtien 1980). Foraging practices among mobile pastoralists are mentioned in many accounts from early European explorers in the region (for examples, see Vainshtien 1980). Foraging is often overlooked or ignored in archaeological models for people who also practice food production (i.e. agriculture or pastoralism); however, it can complement other economic pursuits, especially mobile pastoralism. The wild fruits identified at Sarazm include Russian olive, hackberry, sea buckthorn berry and rosaceous relatives
(Prunus and possibly Rosa). In addition, shell fragments of wild pistachio (Pistacia vera) and a single capper (Capparis sp.) were recovered. Ubiquities are very low; however, fruits are less likely to become incorporated into a carbonised macrobotanical assemblage than grains because they are often consumed raw. All of these trees are represented in the charcoal assemblage as well.

\section{Wild herbaceous seeds}

The overall abundance of wild seeds in the Sarazm assemblage is much lower than at other Central Asian sites. This is likely to be a result of the use of wood as a major fuel source at Sarazm. Central Asian macrobotanical assemblages with high abundance of small wild herbaceous seeds are usually interpreted as reflecting the use of dung as fuel. When the dung of grazing animals, laden with seeds, is burned it produces ash rich with charred seeds (for a discussion, see Miller 1996). Seeds from Sarazm such as Galium, Plantago, or Chenopodium, are typically found in such assemblages. Wood availability and abundance should not be used to argue against dung burning in the archaeological record. Modern mobile pastoralists in the Semirech'ye region of Kazakhstan use dung in combination with riparian wood as fuel (personal observations).

Another explanation for the presence of these small wild seeds is that they were agricultural weeds. During the winnowing and possibly sieving of grains, residue such as rachises and chaff are removed. Likewise, wild seeds are separated from the grain. This residue is often burned or fed to herd animals and later burned as dung; either way wild seeds end up incorporated into the archaeobotanical assemblage. Larger dense wild seeds (such as Lithospermum) have a similar weight and size as domestic grains and are often inadvertently harvested with the grains; furthermore, they may take considerable sieving and hand sorting to remove. Hand sorting would be done in a domestic context, often near a hearth just prior to grain grinding. Therefore, such seeds are more likely to become incorporated. Indeed, Lithospermum is the most abundant of the wild herbaceous seeds at Sarazm. However, members of the Boraginaceae family are common in assemblages from South and Central Asia. They readily preserve due to their hardened biomineralised testa. Furthermore, wild grasses may blend in, unnoticed, in agricultural fields and therefore, have an increased chance of being incorporated into an assemblage and removed later. This is especially the case with large-seeded annual grasses in the Pooideae subfamily which morphologically resemble wheat and barley, such as wild Hordeum spp., Aegilops, Lolium and Bromus. While some of the wild seeds could be the result of sieving or 
sorting residue, it should be noted that rachis material was relatively low in abundance.

As Hastorf and Wright (1998, 222) point out, the vector(s) of introduction for wild herbaceous seeds can rarely be unequivocally determined. Dung burning and grain processing residue are equally likely vectors and could both be responsible for portions of the assemblage. Other vectors may be equally valid including human foraging of wild grains, use of wild plants as bedding, roofing, or floor cover, the use of dry brush as tinder, wind borne seeds, or in certain cases cleaning of wool (e.g. the setose form of Galium).

\section{Charcoal}

Wood charcoal at Sarazm is unusually abundant; most Bronze Age or later sites from Southwest Asia (e.g. Miller 1990; Willcox 2002) and Central Asia (e.g., Miller 1999) have low charcoal abundance. In Central Asia, for at least the past four millennia, herd animal dung was the primary fuel source, although at Sarazm wood was a significant fuel. The ratio of charcoal remains to cereals further supports the high abundance of the former, overall. A significant portion of the samples produced charcoal and no seeds; four samples (FS59, FS61, FS66 and FS70) contained several liters of charred wood each. This indicates that wood for fuel (especially slower growing non-riparian species) was available close to the site in the third millennium BC. It is likely that these trees occupied the alluvial fans of the valley. The steppe environment characteristic of the valley today is maintained primarily through herding. Sometime after the end of the third millennium BC the lower valley was deforested. Deforestation could have been multi-causal due to clearing for agriculture and wood resources (fuel and lumber); wood fuel was not only important for domestic use but also for smelting metal and firing pottery. Young tree growth and regeneration of the forest was likely suppressed through grazing and browsing. Long-term suppression of sapling growth led to expansion of the steppe, composed of grasses that were advantageous to herders, but also less nutritious forage plants such as Artemisia sp. and Salsola sp. This is likely the case for much of the Central Eurasian mountain zone. Similar findings have been noted using archaeological wood charcoal for much of Southwest Asia (Willcox 2002).

Carbonised wood remains were analyzed from 44 samples; ubiquities have been assigned based on the percentage of samples a certain category of wood appears in (Table 2). For example, willow/poplar wood was the most common, appearing in $79.5 \%$ of the samples. Eight wood categories were identified (including reed culms). Of these, three are characteristic river forest plants, Salicaceae, Tamarix and reed grass (Phragmites australis [Cav.] Trin. or Arundo donax L.). The rest are from higher elevation forest wood.

The presence of juniper (Juniperus sp.) at the nearby Buddhist site of Penjikent (noted by Willcox during excavations) is interesting because currently juniper only grows above 2000 masl. Juniper wood has been identified at other low-elevation sites in South Asia, such as Mehrgarh (Thiebault 1988, 506), Pakistan, at an elevation of 142 masl; Kandahar (Willcox 1991, 123), Afghanistan, at 1000 masl; Tal-e Malyan (Miller 1985, 5), Iran, at 1600 masl (Carter 1943); and the Dam Dam Cheshme Rockshelters, Turkmenistan, at an elevation of 300 masl (Harris 2010, 35, 199-200). In all of these regions today juniper only grows at high elevations and in remnant populations. The presence of juniper wood in these assemblages may suggest two possibilities and probably a combination of the two: (1) people were moving to higher elevations to collect juniper wood, which was either directly or indirectly used as fuel; and/or (2) juniper grew at much lower elevations in the second, third and fourth millennia BC.

It is clear that some of the charcoal in the assemblage was also used as architectural material. This was most clearly depicted in FS34 where charred beams were excavated in situ; the house structure was burned leaving copious carbonised wood remains. These structural beams were made of wood from Salix/Populus and Prunus (Amygdalus). A charred beam of Prunus (Amygdalus) was also found at the locus of FS37. Reed culms were found in a number of samples; reeds are often used as roofing or architectural material in Central Asia today (personal observations, 2006-2011).

Several edible fruit and nut trees such as Celtis and Pistacia vera are represented in the charcoal assemblage. However, it is likely that these trees were not as readily targeted as a wood source, but rather preserved for their more significant economic use - nuts and fruits.

\section{Discussion and interpretation}

There are archaeobotanical similarities between the Sarazm assemblage and assemblages from the Kopet Dag Mountains some $400-500 \mathrm{~km}$ to the southwest. For example, the lack of pulses at Sarazm is similar to the Neolithic and Early Bronze Age material from Jeitun and Anau (Harris 2010). Middle and Late Bronze Age sites in southern Central Asia have chickpeas (Cicer sp.), lentils (Lens sp.), green peas (Pisum sativum L.) and possible grass peas (cf. Lathyrus) (Miller 1999; Moore et al. 1994). However, fourth and early third millennia BC sites do not have any good evidence for pulses (Harris 2010). It seems 
likely that these domestic legumes were introduced to Central Asia from the Iranian Plateau in the Middle Bronze Age (ca 2500 BC). One Fabaceae specimen, identified as Lens sp., was recovered from Sarazm but its wild or domestic status is unclear.

Interestingly, broomcorn millet (Panicum miliaceum L.) is not present at Sarazm. This cereal is completely absent from all of the Kopet Dag Mountain sites (except Tahirbaj Depe mentioned in Herrmann and Kurbansakhatov 1998) and is not present in the earliest layer at Shortughai. It does appear in the second millennium BC at Shortughai (Level II, Period I Willcox 1991). However, it is present in northern Central Asia by $2200 \mathrm{cal} \mathrm{BC}$ at Begash (Frachetti et al. 2010) (Fig. 1). There is an ongoing debate over the origin and monophylly of broomcorn millet (see Hunt et al. 2008, 2011). However, the lack of any solid evidence for domestic broomcorn millet across the western steppe, Southwest Asia and western Central Asia, may suggest that early broomcorn millet at Begash and Shortughai originally was brought from the area of the modern province of Xinjiang, China (see Flad et al. 2010; Frachetti et al. 2010). The lack of any of these grains at Sarazm or any site before the end of the third millennium BC may suggest that this species did not spread into Central Asia from China until after this date.

A combination of archaeological and genetic research over the past few years has clarified much of the picture of barley domestication. It is clear that sixrowed forms were cultivated by ca 7300-6700 cal BC (Zohary et al. 2012, 56), the mutation of the $\operatorname{Vrs} 1$ allele having possibly originated repeatedly in different geographic areas at different times (Komatsuda et al. 2007; Morrell and Clegg 2007). By 6000 BC, naked barley (mostly six-rowed) was cultivated in Southwest Asia (Zohary et al. 2012) and present at Mehrgarh by the fifth millennium BC (Costantini 1984). Taketa et al. (2008) suggest, based on genetic evidence, that a monophyletic mutation of the nud locus caused the naked phenotype of barley. In the fifth and fourth millennia $\mathrm{BC}$ there seems to be a trend across the Caucasus and the Mediterranean for replacing hulled populations by their naked equivalents. Late Neolithic and Early Bronze Age barley at Jeitun and Anau is a mix of hulled and naked morphotypes (Harris 2010), as at Sarazm. By the Middle Bronze Age at Gonur Depe, the hulled form seems to be completely replaced (Miller 1999). Hulled barley is, however, found at Shortughai (Willcox 1991).

Similarly, the general morphology of naked barley grains from Sarazm seems to match sites further south and east. The naked barley at Sarazm is relatively short and plump, similar to grains found in Pakistan (e.g. Mehrgarh and Nausharo (Costantini 1984)) and further south in Miri Qalat, Makran 
(Tengberg 1999) as well as the earliest (second millennium BC) barley in western China (Flad et al. 2010; Fu 2001; Jia et al. 2011).

\section{Conclusion}

The data presented in this article show that Sarazm was a sedentary agropastoral settlement. People at the site from the terminal Eneolithic through the Middle Bronze Age were focused on an array of economic pursuits including craft production, such as metallurgy, and they engaged in a mixed production economy as well as foraging for wild fruits and nuts. While archaeological populations of the Central Asian steppe and mountain region are often labeled as mobile pastoralists, it is becoming increasingly clear that such a label pigeon-holes economies in a way that obscures the reality of subsistence and exchange. As Salzman (1971, 2004) points out in his discussion of multiresource pastoralism, mobile pastoralists are never purely pastoral. Not only it is becoming clear that early mobile pastoralists in the Central Asian mountains used agricultural goods in their economy (Frachetti et al. 2010; Jia et al. 2011), but it is also evident that at various times people in this region were partaking in sedentary or semisedentary agricultural pursuits (Chang et al. 2003; Rosen et al. 2000).

The abundance of wood charcoal in the assemblage suggests that the local vegetation community was drastically different in the past. While riparian forests are still present in the valley, higher elevation forests are nearly absent in the region today. It seems evident that these forests existed much closer to the site in the fourth and third millennia BC. After deforestation, regeneration was likely repressed due to grazing. Thousands of years of grazing in the valley have encouraged steppe species, which are in many cases better suited for pastoral grazing.

Sarazm is not only a key site for understanding the nature of exchange and interaction through Central Asia but also the spread of agriculture into this part of the world. Sarazm may represent one of the earliest agricultural settlements in the eastern margin of the Kyzylkum Desert situated in the foothills of the Hissar range. People living at the site in the third and fourth millennia $\mathrm{BC}$ were growing free-threshing wheat and both hulled and naked varieties of barley. They were also collecting wild fruits and nuts as complements to an agropastoral economy. The multiresource mixed agropastoral economy at Sarazm adds to our growing understanding of the diversity of economic systems that were employed by peoples in Central Asia through time.

\section{Acknowledgments}

Excavations were directed by $\mathrm{R}$. Besenval and A. Isakov during the 1980 s. Some of the flotation was conducted by $\mathrm{R}$. Besenval and his team. The rest of the flotation and all of the analysis and interpretation was conducted by G. Willcox. The map in Fig. 1 was produced by Lynne Rouse (Washington University in St. Louis). Photos in Figs. 2 and 3 were taken by Michael Frachetti (Washington University in St. Louis) at the Sarazm site in 2010.

\section{References}

Besenval, R. 1987. Découvertes récentes à Sarazm (R.S.S. du Tadjikistan): Attestation des relations au IIIe Millénaire Entre l'Asie Centrale, l'Iran du Nord-Est et le Baluchistan. Comptes-rendus des séances de l'Académie des Inscriptions et Belles-Lettres, 131e année 2, 441-56.

Besenval, R. 2001. Brève notice sur la coopération Archéologique Franco-Tadjike. Cahiers d'Asie Centrale. [online, accessed February 27, 2012 - http://asiecentrale.revues.org/index645. html]

Besenval, R. and Isakov, A. 1989. Sarazm et les débuts du peuplement agricole dans la Région de Samarkand. Arts Asiatiques 44, 5-20.

Carter, E. 1943. Excavations at Anshan (Tal-e Malyan): the Middle Elamite Period. Philadelphia: The University Museum University of Pennsylvania.

Chang, C., Benecke, N., Grigoriev, F. P., Rosen, A. M. and Tourtellotte, P. A. 2003. Iron Age society and chronology in South-east Kazakhstan. Antiquity 77(296), 298-312.

Costantini, L. 1984. The beginning of agriculture in the Kachi Plain: the evidence of Mehrgarh, pp. 29-33 in Allchin, B. B. (ed.), South Asian Archaeology 1981. Cambridge: Cambridge University Press.

Crawford, H. 1992. An early dynastic trading network in North Mesopotamia, pp. 77-82 in Charpin, D. and Joannes, F. (eds.), La Circulation des Biens, des Personnes et des Idees dans le Proche-Orient Ancien. Paris: Recherche sur les Civilisations.

Flad, R., Li, S., Wu, X. and Zhao, Zh. 2010. Early wheat in China: results from new studies at Donghuishan in the Hexi Corridor. Holocene 17, 555-60.

Frachetti, M. D. 2008. Pastoralist Landscapes and Social Interaction in Bronze Age Eurasia. Berkley: University of California Press.

Frachetti, M. D. 2012. Multi-regional emergence of mobile pastoralism and non-uniform institutional complexity across Eurasia. Current Anthropology 53(1), 2-38.

Frachetti, M. D. and Mar'yashev, A. N. 2007. Long-term occupation and seasonal settlement of eastern Eurasian pastoralists at Begash, Kazakhstan. Journal of Field Archaeology 32(3), $221-42$.

Frachetti, M. D., Spengler, R. N., Fritz, G. J. and Mar'yashev, A. N. 2010. Earliest direct evidence for broomcorn millet and wheat in the Central Eurasian steppe region. Antiquity 84, 993-1010.

Fritz, G. 2005. Palaeoethnobotanical methodology and applications, pp. 773-834 in Herbert, D., Maschner, G. and Chippindale, C. (eds.), Handbook of Archaeological Methods. Lanham, Maryland: AltaMira Press.

$\mathrm{Fu}$, D. 2001. Discovery, identification and study of the remains of Neolithic cereals from the Changguogou site, Tibet [in Chinese]. Kaogu 3, 66-74.

Fuller, D. Q. 2009. Framing a Middle Asian Corridor of Crop Exchange and Agricultural Innovation. Kyoto, Japan: Harvard University Roundtable on Ethnogenesis of South and Central Asia.

Fuller, D. Q. and Stevens, C. J. 2009. Agriculture and the development of complex societies, ppp. 37-57 in Fairbairn, A. and Weiss, E. (eds.), From Foragers to Farmers: Papers in Honour of Gordon C. Hillman. Oxford: Oxbow Books.

Harris, D. 2010. Origins of Agriculture in Western Central Asia: An Environmental-Archaeological Study. Philadelphia: University of Pennsylvania Museum of Archaeology and Anthropology.

Hastorf, C. A. and Wright, M. F. 1998. Interpreting wild seeds from archaeological sites: A dung charring experiment from the Andes. Journal of Ethnobiology 18, 211-27.

Herrmann, G. and Kurbansakhatov, K. 1994. The international Merv Project preliminary report on the second season (1993). Iran 32, 53-75. 
Hunt, H. V., Linden, M. V., Liu, X., Motuzaite-Matuzeviciute, G., Colledge, S. and Jones, M. K. 2008. Millets across Eurasia: chronology and context of early records of the genera Panicum and Setaria from archaeological sites in the Old World. Vegetation History and Archaeobotany 17, S5-18.

Hunt, H. V., Campana, M. G., Lawes, M. C., Park, Y.-J., Bower, M A., Howe, C. J. and Jones, M. K. 2011. Genetic diversity and phylogeography of broomcorn millet (Panicum miliaceum L.) Across Eurasia. Molecular Ecology 20, 4756-71.

Isakov, A. 1980. Excavations of the Bronze Age settlement of Sarazm. Anthropology and Archaeology of Eurasia 19, 273-86.

Isakov, A., Kohl, P. L., Lamberg-Karlovsky, C. C. and Maddin, R. 1987. Metallurgical analysis from Sarazm, Tadjikistan SSR. Archaeometry 29(1), 90-102.

Jia, P. W., Betts, A. and Wu, X. 2011. New evidence for Bronze Age agricultural settlements in the Zhunge'er (Junggar) basin, China. Journal of Field Archaeology 36(4), 269-80.

Kenoyer, J. M. 2011. Preface in Law, R. W. (ed.), Inter-Regional Interaction and Urbanism in the Ancient Indus Vallev: A Geologic Provenience Study of Harappa's Rock and Mineral Assemblage (Occasional Paper 11: Linguistics, Archaeology and the Human Past). Kyoto: Indus Project, Research Institute for Humanity and Nature.

Kircho, L. B. 1980. The problems of the origin of the Early Bronze Age culture of Southern Turkmenia. Anthropology and Archaeology of Eurasia 19, 96-106.

Kohl, P. L. 1980. The Namazga civilization: An overview. Anthropology and Archaeology of Eurasia 19, 7-37.

Komatsuda, T., Mohammad, P., He, C., Perumal, A., Hiroyuki, K., Dragan, P., Stein, N., Graner, A., Wicker, T., Tagiri, A., Lundquist, U., Fujimura, T., Matsuoka, M., Matsumoto, T. and Yano, M. 2007. Six-rowed barley originated from a mutation in a homeodomain-leucine zipper 1-class homeobox gene. Proceedings of the National Academy of Sciences of the United States of America 104(4), 1424-9.

Law, R. 2006. Moving mountains: the trade and transport of rocks and minerals within the Indus valley region, pp. 301-13 in Robertson, E. C., Seibert, J. D., Fernandez, D. C. and Zender, M. U. (eds.), Space and Spatial Analysis in Archaeology. Albuquerque: University of New Mexico Press.

Lyonnet, B. and Isakov, A. I. 1996. Sarazm (Tadjikistan) Céramiques: Chalcolithique et Bronze Ancien. Paris: De Boccard.

Masson, V. M. 1980. Altyn-depe during the Aeneolithic period. Anthropology and Archaeology of Eurasia 19, 63-95.

Mei, J. 2009. Early metallurgy and socio-cultural complexity: archaeological discoveries in Northwest China, pp. 215-34 in Hanks, B. K. and Linduff, K. M. (eds.) Social Complexity in Prehistoric Eurasia: Monuments, Metals, and Mobility. Cambridge: Cambridge University Press

Mei, J. and Shell, C. 1999. The existence of Andronovo cultural influence in Xinjiang during the 2nd Millennium BC. Antiquity 73(281), 570-8.

Miller, N. F. 1985. Paleoethnobotanical evidence for deforestation in ancient Iran: a case study of urban Malyan. Journal of Ethnobiology 5(1), 1-19.

Miller, N. F. 1990. Godin Tepe, Iran: plant remains from period V, the Late Fourth Millennium B.C. Museum Applied Science Center for Archaeology Ethnobotanical Report 6, 1-12.

Miller, N. F. 1996. Seed eaters of the ancient Near East: Human or herbivore? Current Anthropology 37(3), 521-8.

Miller, N. F. 1999. Agricultural development in Western Central Asia in the Chalcolithic and Bronze Ages. Vegetation History and Archaeobotany 8, 13-9.

Moore, K., Miller, N. F., Heibert, F. T. and Meadow, R. H. 1994 Agriculture and herding in early oasis settlements of the Oxus Civilization. Antiquity 68, 418-27.

Morrell, P. L. and Clegg, M. T. 2007. Genetic evidence for a second domestication of Barley (Hordeum vulgare) east of the Fertile Crescent. Proceedings of the National Academy of Sciences of the United States of America 104, 3289-94.

Parpola, S., Parpola, A. and Brunswig, R. H., Jr. 1977. The Meluhha village. Evidence of acculturation of Harappan traders in the Late Third Millennium Mesopotamia? Journal of the Economic and Social History of the Orient XXII, $129-65$.

Pearsall, D. M. 2000. Paleoethnobotany a Handbook of Procedures. San Diego: Academic Press.

Possehl, G. L. 2004. The Middle Asian interaction sphere: trade and contact in the 3rd Millennium BC. Expedition 49(1), 40-2.

Razzokov, A. 2008. Sarazm. Dushanbe: Institute of History, Archaeology, and Ethnography [in Russian]. Dushanbe, Tajikistan: Academy of Sciences of Tajikistan A. Danish History, Archaeology and Ethnographic Institute.

Rosen, A. M., Chang, C. and Grigoriev, F. P. 2000. Paleoenvironments and economy of Iron Age Saka-Wusun agro-pastoralists in Southeastern Kazakhstan. Antiquity 74, 611-23.

Salvatori, S. 2008. A new cylinder seal from ancient Margiana: cultural exchange and syncretism in a "world wide trade system" at the end of the 3rd Millennium BC, pp. 111-8 in Salvatori, S. and Tosi, M. (eds.), The Bronze Age and Early Iron Age in the Margiana Lowlands Facts and Methodological Proposals for a Redefinition of the Research Strategies (British Archaeological Reports International Series 1806). Oxford: Archaeopress.

Salzman, P. C. 1971. Movement and resource extraction among pastoral nomads: the sase of the Shah Nawazi Baluch. Anthropological Quarterly 44(3), 185-97.

Salzman, P. C. 2004. Pastoralist: Equality, Hierarchy, and the State. Boulder, Colorado: Westview Press.

Sarianidi, V. 1993. Excavations at Southern Gonur. Iran 31, 25-38.

Taketa, S., Amano, S., Tsujino, Y., Sato, T., Saisho, D., Kakeda, K., Nomura, M., Suzuki, T., Matsumoto, T., Sato, K., Kawasaki, S. and Takeda, K. 2008. Barley grain with adhering hulls is controlled by an ERF family transcription factor gene regulating a lipid biosynthesis pathway. Proceedings of the National Academy of Sciences of the United States of America 105(10), 4062-7.

Tengberg, M. 1999. Crop husbandry at Miri Qalat, Makran, SW Pakistan (4000-2000 $\quad$ B.C.). Vegetation History and Archaeobotany 8(1-2), 3-12

Terekhova, N. N. 1980. The history of metalworking production among the ancient agriculturalists of Southern Turkmenia. Anthropology and Archaeology of Eurasia 19, 313-24.

Thiebault, S. 1988. Palaeoenvironment and ancient vegetation of Baluchistan based on charcoal analysis of archaeological sites. Proceedings of the Indian National Science Academy 54(3), 501-9.

Thornton, C. and Schurr, T. G. 2004. Genes, language, and culture: an example from the Tarim Basin. Oxford Journal of Archaeology 23(1), 83-106.

Vainshtien, S. 1980. Nomads of South Siberia the Pastoral Economies of Tuva. Colenso, M. (transl.), Cambridge: Cambridge University Press.

Watson, P.-Jo. 1976. In pursuit of prehistoric subsistence: a comparative account of some contemporary flotation techniques. Mid-Continental Journal of Archaeology 1, 77-100.

Willcox, G. 1991. Carbonized plant remains from Shortughai, Afghanistan, pp. 139-53 in Renfrew, J. M. (ed.), New Light on Early Farming: Recent Developments in Palaeoethnobotany. Edinburgh: Edinburgh Press.

Willcox, G. 2002. Evidence for ancient forest cover and deforestation from charcoal analysis of ten archaeological sites on the Euphrates, pp. 141-5 in Thiébault, S. (ed.), Charcoal Analysis. Methodological Approaches, Palaeoecological Results and Wood Uses (British Archaeological Reports International Series 1063). Oxford: Archaeopress.

Williams, D. 1973. Flotation at Siraf. Antiquity XLVII, 288-92.

Winkelmann, S. 2000. Intercultural relations between Iran, the Murghabo-Bactrian Archaeological Complex (BMAC), Northwest India and Failaka in the Field of Seals. East and West 50, 43-95.

Zohary, D., Hopf, M. and Weiss, E. 2012. Domestication of Plants in the Old World: the Origin and Spread of Domesticated Plants in Southwest Asia, Europe, and the Mediterranean Basin (4th ed.). Oxford: Oxford University Press. 